\section{Equal Pay for Women after the Employment Contracts Act: Legislation and Practice - the Emperor with No Clothes?}

\section{Prue Hyman*}

This paper outlines the changes to the Equal Pay Act 1972 and other relevant legislation made at the time of the passage of the Employment Contracts Act and discusses what meaning and coverage remains. It suggests that the legal uncertainties and accentuation, in the current economic and industrial relations climate, of previous difficulties in using the legislation render it almost useless.

\section{Introduction}

This paper focuses on discussing the practical value, if any, of the Equal Pay Act 1972 in the 1990s. However, before dealing with this issue, I make some general observations on the Employment Contracts Act, labour market deregulation, and the implications for women employees.

The Minister for Women's Affairs was quoted in the Evening Post (1-12-1992) as claiming that it "has done more towards providing equity for working women than any other development for a long time". She gave Quarterly Employment Survey (QES) figures showing an increase in average hourly earnings for women of $2.6 \%$ between May 1991 and May 1992. (Incidentally, the fact that this data source showed only a 1.6\% increase, which is still misleadingly high, for the August year got less publicity!) Her comments provoked strong reaction from some quarters, with Helen Clark alluding to a $10 \%$ drop in women's overtime earnings, the over-representation of women in the low paid section of the workforce which had been adversely affected by the Act, and attacks on wages and conditions in female dominated occupations. The Council of Trade Unions (CTU) National Women's Committee Convenor called the Minister's claims that women were happy with the Act "outrageous and insulting".

Commenting on the issue of earnings growth, a number of surveys have quoted two to three percent average annual increases for all or parts of the workforce covered. However, considerable caution is needed in interpreting these figures. First, the same groups are not covered at the beginning and end of the period: if employment reductions are disproportionately among the lower paid, increases will be exaggerated. Second, coverage generally needs examination: for example, the QES excludes small workplaces, while contracts submitted to the Department of Labour may not be representative of all collective contracts covering 20 or more employees, let alone individual and smaller contracts. Third there needs to be care that tradeoffs of improved basic earnings for reductions in penal and overtime rates are fully reflected. In some cases allowances have been incorporated into basic pay.

Raymond Harbridge's contract database, comparing the same group over time, shows only a tiny increase in earnings - of about $0.1 \%$ on an annual basis, and he has amplified the points above, showing why his figures are a truer reflection of reality (Harbridge, 1993). This illustrates the need for more adequate data. It is not a matter of chance that it is not available: it comes from government philosophy and policies in the industrial relations area, as well as inadequate research funding, and helps politicians in their misinterpretation of official statistical sources.

More generally, the claim that a deregulated labour market benefits women needs critical scrutiny (Du Plessis Novitz and Jaber, 1990). Certainly in terms of numbers employed and unemployed, women have done slightly less badly than men over the recent period of substantial job loss. However, this is largely because of women's over-representation in part time, casualised and low wage sections of the labour market, and in industries/occupation which are under less employment pressures. Predictions and some evidence are that the impact of deregulation on those in the casualised secondary sector is negative (Harbridge 1993; Sayers, 1991). The labour market flexibility enhancement purpose of the ECA has been claimed potentially to advantage employees in general, and women in particular. However, such flexibility is mainly at the behest of and for the benefit of employers. Only the small proportion of women in highly scarce occupations are likely to be able to bargain flexibility gains of their own.

Detailed discussion of the concept of gender discrimination in the labour market in general or in pay in particular is beyond the scope of this paper. Among important aspects of any full discussion are competitive and discriminatory aspects of markets, the respective roles and proportion of the gap accounted for by human capital differences and returns, and the utility or otherwise of earnings function studies in assessing the extent of discrimination (Hyman 1992). Equal pay for work of equal value, the principle underlying the pay equity part of the short lived Employment Equity Act, no longer has any legal underpinning. The apparently simpler equal pay for identical work was never as simple as it might seem. It becomes even more elusive in a highly deregulated labour market with inter firm and regional differences for otherwise the same work, and with individualised and performance based pay increasingly prevalent. Nevertheless, the Equal Pay Act 1972 (hereafter, EPA) is still on the books, so whether it, and other anti discriminatory legislation, has any substantial meaning and effect should be examined.

This paper will first outline the legislation before and after the amendments made at the time of the Employment Contracts Act 1991 (hereafter ECA), then discuss its effectiveness or otherwise and draw some fairly depressing conclusions. Some possibilities for progress will be suggested. 


\section{The legislative changes}

Discrimination in employment on the grounds of gender is unlawful under the Human Rights Commission Act 1977 (hereafter HRCA). Section 15(1)(a) makes unlawful a refusal, on the basis of sex and the other grounds covered, to employ a person on work of any description which is available and for which that person is qualified. Section15(1)(b) provides that "No employer shall refuse or omit to offer or afford any person the same terms of employment, conditions of work, fringe benefits, and opportunities for training, promotion, and transfer as are made available for persons of the same or substantially similar qualifications employed in the same or substantially similar circumstances on work of that description" on the basis of the sex (or other grounds covered) of that person.

Until 1991, no complaint referring solely to equal pay was to be dealt with under this legislation (see s15(12)). It was, instead, to be referred by the Commission to the Secretary of the Labour Department for consideration under the EPA. Issues such as possible discrimination in placement on scales and access to promotion are on the borderline of equal pay and gender discrimination/equal opportunity, and thus their status was unclear. The Air New Zealand air hostess case involved access to promotion, among other matters, and was taken to a successful conclusion under the HRCA. The Equal Pay Amendment Act 1991, passed alongside the ECA, repealed s15(12) of the HRC, permitting the Human Rights Commission to pursue a complaint on equal pay itself.

The approach of the EPA to the meaning of equal pay was to prohibit differentiation based on sex. The EPA defines equal pay as "a rate of remuneration for work in which rate there is no element of differentiation between male employees and female employees based on the sex of the "employees" (s2(1)). The major problems were the criteria for establishing such differentiation and the resulting interpretation and enforcement, almost all of which are exacerbated by the recent labour market and industrial relations legislation changes.

Section 3(1) sets out the criteria to be applied in determining whether an element of such differentiation based on sex exists for work covered by any instrument. These criteria are:

(a) For work which is not exclusively or predominantly performed by female employees - (i) The extent to which the work or class of work calls for the same, or substantially similar, degrees of skill, effort, and responsibility; and (ii) The extent to which the conditions under which the work is to be performed are the same or substantially similar:

(b) For work which is exclusively or predominantly performed by female employees, the rate of remuneration that would be paid to male employees with the same, or substantially similar, skills, responsibility, and service performing the work under the same, or substantially similar, conditions and with the same, or substantially similar, degrees of effort.

The Equal Pay Amendment Act added to the definition of instrument in the EPA by including "an employment contract within the meaning of the ECA 1991". Other amendments primarily allowed for institutional change, substituting the Employment Tribunal for previous institutions. Also added was s2A(1), prohibiting discrimination in terms and conditions on the basis of gender in a similar way to the portion of the HRCA quoted earlier. The ECA, too, has similar wording in the definition of discrimination within the personal grievance provisions.

It appears, therefore, that three alternative procedures are now available for equal pay or opportunity complaints: under the EPA, the HRCA, or the personal grievance procedures of the ECA. Whether any of these is likely to be effective, and in what circumstances, is examined next.

\section{Effectiveness of equal pay legislation before and after the Employment} Contracts Act

\section{(a) Before the Employment Contracts Act}

Most of the (highly limited) effectiveness of the EPA in reducing gender pay discrimination and narrowing the overall gender pay gap arose from the elimination of separate male and female rates in awards, agreements, scales, and other collective agreements. The Equal Pay Review Committee (1979) and Urban Research Associates, Hyman and Clark (1987) document changes in the female male earnings gap. In brief, the ratio for average hourly earnings narrowed from about $73 \%$ to $78 \%$ during the implementation period and has since increased very slowly to about $81 \%$. The ongoing slight increase is probably largely due to women's slow rise in vertical job hierarchies.

There are a number of other forms of possible gender discrimination in remuneration, each of which is hard to address:

(i) Using separate job titles for the same work, with one job title used for male jobs, the other for female jobs, and the former being paid more

(ii) Unequal above instrument/contract payments based on gender

(iii) Unequal application of criteria for starting salaries, placing employees on scales, promotion etc, based on gender

(iv) Unequal application of performance pay, merit pay etc, based on gender

(v) Unequal pay for individuals or small groups, with some gender element, when remuneration is fixed by individual contracts or collective contracts with only a few workers

(vi) Undervaluation of female dominated types of work

The possible inequalities in (ii) to (v) may or may not be deliberate. If they are unintended, but arise from criteria some or all of which have a differential effect by gender, and which are not clearly related to productivity on the job, they should still be classified as discriminatory (indirect discrimination).

Categories (i) and (ii) were clearly covered by the Equal Pay Act, but are hard to police Categories (iii) and (iv) can be thought of as variations of (ii) applicable to individuals rathe than groups, and to the person in the job, rather than the job itself. They are on the equal pay/opportunity border. Category (v) can arise from any of the previous four, where small groups are involved, or be independent of them. Category (vi) refers to absence of equal pay 
for work of equal value - and will not be regarded as discriminatory by those who see the market as the sole and nondiscriminating measure of value. The wording of the EPA appears to be supportive of the equal value principle, by requiring job classification exercises in female dominated work to assess what would be paid to men with similar levels of skill, responsibility and effort.

However, only narrow comparisons were made and the Act was largely ineffective in this area. (Urban Research Associates op. cit; Orr, 1986a). Equal value was more directly covered in the short-lived Employment Equity Act, passed and repealed in 1990.

Even in female dominated work where job classification exercises were undertaken and led to an increase in remuneration, there has been a period of up to 19 years in which relativities may have changed to the detriment of such work. The 1986 Clerical Workers case in which the union sought a judgement that the employers must negotiate on equal pay (for work of equal value) demonstrated this effect. The grade 3 hourly rate in the Clerical Award, predominantly female, was $69 \%$ of the average male hourly wage rate in 1974 . This ratio rose to $79 \%$ in 1979 with equal pay implementation, but fell back to $72 \%$ by 1985 . Its ratio to core carpenter and journeyman printers rates had returned by then to the 1973 figure (New Zealand Federated Clerical, Administrative and Related Workers Industrial Association of Workers, 1986).

The judgement in the Clerical Workers case in 1986 effectively closed off use of the Act in this area. However, the erosion of the results of job classification exercises undertaken under the Equal Pay Act with respect to female dominated work shows the need for change. The Act, as interpreted by the then Arbitration Court, does not allow a further job classification exercise to be insisted on by the union to address such possible erosion.

The Equal Pay Review Committee was concerned about each of the problem areas mentioned above, as well as the means of enforcement. Investigation of possible problems in any of the areas (ii) to (v) requires detailed assessment of individual or small group remuneration in comparison with that of a man or men.

Discrimination in individual cases is much harder to establish than separate rates in an award. Individual complainants were covered by the Act through their instrument coming under s2(1)(e) or 2(1)(f) of the definition of instrument. This is critical because s2(2) qualifies just these types of instrument. It reads:

Nothing in this Act shall apply with respect to any agreement specified in paragraph (e) the definition of the term "instrument" in subsection (1) of this section made between the definition of the terl an individual employee and an individual employer, or any decision under paragraph (f) of that definition made in respect of an individual employec, which ixxes a rate of remuneration that is special to that employee by reason of special qualifications, experience, or other qualities possessed by that employee and that does not involve any discrimination based on the sex of the employee.

This applies to contracts under the ECA which have been added to 2(1)(e).
Two problems arise with regard to $\mathrm{s} 2(2)$. The first is the generality of this exemption, since it removes the obligation of the employer to make a collective determination prior to identifying the factors special to individual employees. The requirement not to discriminate on the basis of the sex of the employee is still present, but without such a determination it is almost impossible to establish whether an element of discrimination exists (Equal Pay Review Committee, 1979: 52). The Review Committee feared that this would act as a general escape clause of wider application than intended, and suggested amendments - which were not made.

The second, related problem is the broad interpretation by the then Arbitration Court, which seems to make it possible for employers always to find a justifying factor for pay differences. The Review Committee and one of its members, Elizabeth Orr (1986b) expressed disquie about the judgements in a number of cases and the arguments made by employers and accepted by the Court. Only 10 equal pay cases were determined by the Court, 9 during the period 1973/9 and the Clerical Workers case in 1986, which was submitted essentially as a test case on the continuing applicability of the act and whether it genuinely covered equal pay for work of equal value. The lack of other cases after 1979 reflects both the completion of the implementation period and a belief by unions and the inspectorate that the Court was unlikely to interpret the act sympathetically towards claimants (Orr, 1986b: 11). In only two cases did the Court rule in favour of women claimants.

Four of the complaints decided in the 1970s each concerned a single woman (or in one case a small group) comparing their pay with that of a single man in the workforce of the same employer. Each involved above award or non-award rates and each was decided against the claimant. They are relevant here because they most closely resemble the likeliest scenario for complaints under the ECA. In each case, factors other than gender were found to accoun for the pay differences. The most crucial, Inspector v D.F. Jones, [1979] AC D.1008 71/2, related to two accountant-clerks employed in the same firm and location, on work which the judgement stated was broadly similar in content. However, in the words of the judgement, "Mrs Deverick asked for and was granted a salary of \$5,000. Mr Robertson would not accept a post for less money than he was receiving at Massey University. His salary was, by agreement also, fixed at $\$ 7,200^{\prime \prime}$. Mrs Deverick was slightly superior in initial qualifications and Mr Robertson had more experience in general administration. The Court ruled that "whatever way the matter is looked at and whatever criteria are applied, there has been no element of differentiation based on the sex of Mrs Deverick", attributing the difference to the man's greater experience.

The 1979 Review Committee was unhappy with this decision, believing the situation to be based on a dual labour market, related to the greater job opportunities for men compared with married women in professional areas in Palmerston North. "In the committee's view the elimination of just such a sex-biased labour market was and is a major aim of the Equal Pay Act" (Review Committee, 1979: 50). It argued that a dual labour market should not be used to justify differential rates and that the Court should have set a common rate for the work and then assessed the payment for the two special factors listed, one on each side. It felt that a differential as large as $44 \%$ would be hard to justify on experience alone.

In reviewing this and the other cases, the question arises as to what evidence would have been sufficient to convince the Court that discrimination had occurred (Orr, 1986a: 11). It is not 
surprising that after these determinations neither inspectors nor unions brought any more individual cases to court

Instead, the efforts of women's organisations and unions, particularly after the 1986 judgement, were concentrated on securing better legislation. Attempts to use the collective bargaining system to obtain equal pay for work of equal value were also made, but without legislative/judicial back up successes have been highly limited. Industrial action has been used occasionally. In 1974 women supermarket meatpackers struck over the fixing of the notional man's rate at the level previously paid to women. With support from transport unions, strike action remedied the situation (Osborne, 1976: 354). However, in the changed economic and industrial relations climate of the late 1980s and early 1990s, strike action is less likely to succeed.

\section{(b) After the Employment Contracts Act}

The first new issue which arises after the ECA is what types of complaints/cases it is possible to pursue. The EPA makes unlawful gender differentiation in remuneration payable for any work 'under any instrument', with the ECA extending part (e) of the definition of instrumen to include contracts under the ECA, as mentioned earlier. Parts (e) and (f) of the definition of instrument previously covered agreements (in the general, not technical sense) and decisions fixing remuneration between individual employees (or a group) and employers. This clearly makes unlawful unequal pay based on gender within the same contract However, it is less clear whether unequal pay based on gender (as defined by the Act and interpreted by the judicial system, and if it could be established) across contracts is unlawful. If not, those on individual contracts would now have no coverage at all. Different legal opinions have been expressed on this issue, and only a court decision would give a definitive answer.

Hopefully, a complaint based on alleged gender pay difference for the same or substantially similar work for the same employer would be entertained, even though the female complainant and male comparator were each on individual contracts. This can be seen as in some ways similar to earlier individual cases (see Inspector v D.F. Jones). Previously such claimants could have been under the same instrument (award, agreement etc. covered by parts (a) to (d) of the instrument definition) for their basic pay, but receiving above award payments, bringing them under the rubric of (e) or (f). There might also be circumstances in which it would be desirable to investigate whether equal pay/gender discrimination exists between different collective contracts within the workforce of an employer, but this may be ruled out.

A further possibility is that the addition of $\mathrm{s} 2 \mathrm{~A}(1)$ to the EPA, prohibiting discriminatory treatment, cuts through this issue by allowing at least individual complaints and comparisons within the workforce of the same employer, whatever the contract status. How this section relates to the rest of the Act is not clear and would only be resolved by case law. Doubts exist about whether it can have any real effect in the EPA context, since no complaints procedures or remedies appear to be set down there, unlike the similar provisions in the HRCA and the personal grievance procedures of the ECA.
Even if comparison of individual contracts is possible, the problems of establishing discrimination in individual cases remain. In fact their effects are exacerbated by the combined impact of the ECA and associated changes in economic climate and bargaining levels. First, individual contracts are becoming much more common and remuneration is likely to be more varied by region, industry, firm and other factors. Thus the problems of establishing discrimination in individual cases will apply to a greater proportion of the workforce, and the greater variation will make even more difficult the isolation of a gender factor (or make it easier to cover up). Collective contracts, too, will on average cover less workers and be more locally based.

Second, less people are in a position to know what others are paid, and thus whether there is any discrimination. Only collective contracts with over 20 people covered have to be lodged with the Industrial Relations Service, and access to this information is uncertain. A more general move, for example, in the public service, to privacy of remuneration information, including positions on scales and merit pay, can mask discrimination. Women, especially those in small workplaces, are likely to be reticent about making enquiries and complaints. This may be due to socialisation and/or fears, which may be justified, of retaliation or unpleasantness from the employer or male fellow workers, and of long delays in securing an outcome. These fears are likely to be greater with high levels of unemployment, a climate where the employer has more bargaining power, and substantial stand down periods after voluntarily leaving a job or being dismissed before eligibility for a benefit.

Third, merit and performance pay is becoming more common, and despite the efficiency and equity cases which can be made in favour, there is evidence of potential for unintended gender discrimination (Burton, 1987, 1988 and unpublished paper). Fourth, support from a union may be less available than before with lower levels of union coverage, and other priorities in a more difficult economic and bargaining climate. Fifth, enforcement is likely to be even harder than in the past.

\section{(c) Enforcement}

The enforcement procedure under the EPA was originally based on a combination of response to complaints and an investigation/inspection system to ensure compliance. Employers and trade unions as parties to instruments had the obligation during the implementation period to ensure that work classifications and rate change determinations were made in accordance with the Act. Unions and Labour Department inspectors were able to act as agents of individuals in handling complaints. However, a union had to request the Department of Labour to carry out an investigation rather than undertake one on its own initiative, since only the Department had access to confidential wage records, through the Inspectorate.

The Inspectorate at that stage also covered occupational safety, health and welfare, minimum conditions, such as under the Holidays Act, and wages and awards, including the Equal Pay Act. There was no individual specialisation within the inspectors' overall brief. When inspecting factories, shops and offices, all areas were covered. 
It is clear that enforcement was consistently inadequate, with insufficient numbers of inspectors and with health and safety given priority, in accord with the background of most inspectors. From March 1975 to March 1979 the inspectorate grew from 114 to 203, but the Department in 1979 assessed the desirable establishment at about 320. This was based on the aim of inspecting factories annually and shop, offices and other units biennially. In 1978 only $44 \%$ of factories were inspected, while shops were being visited about every four years and offices at 10 yearly intervals, reflecting the safety priority. Women employees are, of course, more dominant in shops and offices than in factories. By February 1986, the inspectorate had been reduced to 144 field staff. A former inspector, subsequently a union official and now an opposition Member of Parliament, stated that the enforcement of equal pay was very low on the department's priorities and queried the complacency with regard to compliance with the legislation revealed by the department's 1983/4/5 Annual Reports (Tennet, 1986: 3-6).

Several factors make enforcement even harder in the new climate. The reduced level of information available to individual employees, unions or other representatives on remuneration levels of groups and individuals make for difficulty, and increase the costs of attempting to investigate and enforce rights under the EPA. Between 1987 and 1991, under the Labour Relations Act, unions had the right to inspect wage records and were therefore in theory able, if alerted to problems, to take a more active role than previously. The ECA removed this right and thus inspectorate enforcement resumed its previous importance.

The inspectorate has now been divided, with separate administration and responsibility for safety and health, on the one hand, and the minimum code on the other. This might be welcomed if the latter group had both sufficient resources and instructions to enforce equal pay, neither of which is likely to be the case. There are now only seven such inspectors, plus three information officers. Official policy is now to respond to any written complaints, but not to make routine inspections. Since 1980 the number of complaints made under the Act has been very small. The Department of Labour has regularly used this fact to conclude that compliance with the Act is satisfactory, and equal pay has been achieved. For example they unilaterally cancelled the 1982 further review recommended by the 1979 Review Committee. It was argued earlier that the sparsity of complaints relates more to lack of success of earlier cases than to full compliance or acceptance by women that compliance has occurred.

Four complaints have been investigated by the Labour Inspectorate since August 1988. Two appear not to raise important issues in the current context, while one was successfully settled by the female employee with her employer. The fourth was investigated in 1990, following a complaint from the Human Rights Commission that three female employees had been paid salaries lower than a male employed in a similar capacity by the same employer. The employer defended its decision to pay the male a higher rate than one of the females because he had been earning more previously and thus the higher rate was to attract him to the job. The Inspectorate did not consider it worth taking this case to court even though it was hard to substantiate differential skills and experience. Their legal advice was that the Court would accept the previously higher salary as a valid non-gender-related reason for a pay difference. This advice was probably correct in the light of the Jones case, but again allows the perpetuation of gender market differences possibly unrelated to productivity.
A second issue relates to the other rationale given by the employer for the male receiving a higher rate. This was that he had the potential to occupy a more feni the male receiving a o his to be ". Again, the probably correct legal advice was that the Court would conside assessment of potential to

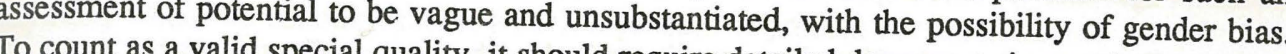
To count as a valid special quality, it should require detailed documentation, and comparison between the two people involved. Otherwise it is open to the types of gender bias present in recruitment and performance assessment, mentioned earlier.

A final point of importance is that it has to be accepted that equal pay complaints are now only possible within the workforce of a single employer, except in the case of the reducin minority of multi employer collective contracts (Harbridge, 1993). While of the reducin the current climate, the concept of the undervaluation of skills in female dominated work which underlies equal pay for work of equal value arguments is an occupationally based one. Cross employer claims were possible under the Employment Equity Act.

With all these problems arising with the Equal Pay Act, and doubts about the likelihood of claims being made and succeeding under personal grievance procedures at the Employment Tribunal, it may be that the Human Rights Commission is now the best of the three option available for pursuing equal pay. The Commission in 1992 investigated a complaint involving equal pay as well as other issues, but as it was settled between the parties with HRC assistance, its nature, unfortunately in this context, cannot be discussed.

It is possible that any Court proceedings under each of the three options would have to be in the Employment Tribunal or Court, since s3(1) of the ECA gives them "exclusive jurisdiction to hear and determine any proceedings founded Human Rights Commission and others consider that complaints contract". However, the can continue to be dealt with, where appropriate, by will now include will now include equal pay cases. It is to be hoped that this interpretation is correct, as the EOT is more specialist and perhaps understanding of gender issues. It also allows the class action possibility under s38(2) of the HRCA.

\section{Conclusion}

From international comparisons, it seems clear that the economic situation, the structures of pay by occupation, industry and gender, industrial relations law and systems, and the political climate are more important in the extent and rate of change of the gender earnings gap than specific pay equity initiatives (Hyman, 1992). Human capital differences account for part of the gap in each country, but institutional factors have a major role. Decentralised systems with largely enterprise bargaining and low levels of unionisation (Japan, the United States) have wider pay gaps, by gender and generally, than more centralised ones.

Econometric studies which standardise for human capital factors have confirmed the importance of pay structures and institutional factors. The much greater reduction and resulting smaller size of the gender earnings gap in Australia compared with the United States cannot be explained by differences in industry mix or human capital endowments (Gregory 
et al., 1989). The impact of the equal value tribunal decisions and centralised pay systems in Australia, contrasting with the deregulated market in the United States, have been the most important influence. Another Australian study, using workplace rather than Census data, concluded that:

For those concerned with ending wage discrimination, the much smaller differentials in Australia would appear to represent a resounding success for the principle of equal pay applied through the awards system. By implication, any attempt to shift the Australian industrial relations system towards the US model might be expected to increase wage discrimination as the "flexibility" of wage setting by employers increases. (Drago, 1989:
323)

The comment applies equally to New Zealand, which has had high levels of centralised bargaining and unionisation by international standards. This is particularly true for women, and such high levels, combined with strong participation in union affairs, appears to be correlated with a lower gender pay gap. (Curtin, 1991; Saar, 1992). In New Zealand part time workers and female dominated areas of work in small workplaces were covered by awards and unionised to a greater extent than in most overseas countries (Hill, 1992). However, this is likely to erode, along with the general fall in collective bargaining and the proportion of the workforce unionised (Harbridge, 1993). Part time work is under-researched in New Zealand with regard to pay and conditions. It is instructive to note that in Australia in 1986, the average hourly wage rate of part-time workers was $20 \%$ above the full-time hourly wage, whereas in the United States part timers in 1987 received hourly wages between $11 \%$ and $44 \%$ below those of full timers (Hawke, 1992). New Zealand's institutional structure having been fairly similar to Australia's in the past, it is likely that we will be moving from something close to the first situation towards the second, to the detriment of women who predominate in part-time work.

The discussion suggests that there is a considerable possibility that the gender gap may widen again in New Zealand, and that discrimination may increase in the current climate. An effective minimum wage is some protection for the lower paid, in which women predominate. In Britain, one strand of the current pay equity campaign is to introduce such a minimum wage. Its retention in New Zealand, preferably with regular increases (none have occurred in the last three years) is an important strand of pay equity for women. Of course, this policy is opposed by those convinced of the existence and strength of a wage employment trade off. The arguments on this issue are beyond the scope of this paper.

Overall the prospects for progress on gender equality and pay equity are far from promising. Only on voluntary (and in the state sector, within limits, compulsory) programmes for equal employment opportunity for women - and the other groups designated in the State Sector Act - is progress reasonably likely. Equal pay is provided for by legislation in most countries, with 107 having ratified ILO Convention 100 by 1986 . This convention is concerned with equal pay for work of equal value, although it is not highly prescriptive with respect to the manner of implementation. It was ratified by New Zealand in 1983 on the basis of the EPA although there is doubt about whether in the current total policy framework, the $\mathrm{IO}$ would regard New Zealand as being in compliance, as it has previously.
What, if anything can be done in the current climate? It is clear that the Equal Pay Act is now unsatisfactory by any standards. It is hard to read, much of it is irrelevant, referring to the implementation period and earlier industrial relations systems, and it is not clearly established what remains in operation. Thus a review is long overdue, although whether anything would be accomplished by such a process at present is questionable.

Probably more in tune than new or revised legislation, with the current non-interventionist stance, is educational and publicity material on gender neutrality in remuneration systems, aimed at individual employers. This could encompass job evaluation schemes and other systems for deciding comparative worth and salaries within firms, placement on scales, and merit/performance pay. One useful resource is the Gender at Work job evaluation scheme (Burns and Coleman, 1991). Such an approach may well fit with the current moves in the area of workplace reorganisation, reform and emphasis on teamwork. These moves offer the opportunity for equity considerations to be blended with efficiency, but also carry the dangers of the process ignoring the needs and potential of women, Maori and other groups currently less advantaged in the workforce. There are a few overseas precedents of workplace restructuring and collective and individual bargaining incorporating moves towards pay equity, using arguments based on both undervaluation of skills and efficiency.

It should be noted that in Ontario the gender neutrality of most standard job evaluation systems, at least in particular applications, is under challenge from unions. In the first major decision defining the standards needed for gender neutral job comparison, in a case based on Haldiman-Norfolk nurses,

the Tribunal held that the Municipality's bargaining practices and proposed job evaluation system prepared by the consulting firm William M. Mercer Limited violated the Act and failed to identify and rectify the systemic discrimination in compensation faced by the Union's Public Health and Homes for the Aged nurses. (Cornish, 1991: 5)

The system was held to have failed to accurately describe, value and make visible the work of the nurses, while the employer ignored criticisms of the system and failed to inform itself about the nurses work. In a second case, the Skew Aitken scheme, which is used in New Zealand, has been ruled not gender neutral in a second hospital setting.

Concern for gender neutrality and efficiency can be subsumed under the rubric of equal treatment, encompassing both equal pay and equal opportunity (Orr, 1988). It is a reasonable approach in the short term, with voluntary compliance only. These ideas already underlie the work of the rather small and toothless, but acceptable Employment Trust, which at least is working for positive change. It could also be an appropriate approach in the medium/long term, if the cycle of the economy, social factors and philosophies at some stage give rise again to a more interventionist climate. At that point, the Ontario model of compulsion for the formation of plans within enterprises might be worth considering, perhaps broadened from pay equity to equal treatment. Whether third party intervention of any form will again become acceptable is uncertain, but there is considerable doubt that major improvements will occur without it.

More fundamentally, the philosophy underlying current policy, which gives primacy to individual freedom of contract in the labour market, like any other, moves away from any 
third party enforcement of equal opportunity or gender neutral comparisons (Dawson, 1992). It is even further, except through lip-service and voluntary measures, from securing gender neutral outcomes or structural change based on feminist perspectives.

\section{References}

Burns, J. and Coleman, M. (1991), Equity at Work - an Approach to Gender Neutral Job Evaluation, Wellington, State Services Commission and Department of Labour.

Burton, C. (1987), Merit and Gender: Organisations and the Mobilisation of Masculine Bias, Australian Journal of Social Issues, 22(2): 424-435.

Burton, C. (1988), Redefining Merit, Canberra, Affirmative Action Agency, Monograph No 2, Commonwealth of Australia.

Burton, C. (n.d.), Report on Gender Bias in the Performance Appraisal Process, Insolv, unpublished paper.

Cornish, M. (1991), Standards for Making Visible and Positively Valuing Women's WorkReview of Jurisprudence under Ontario's Pay Equity Act, unpublished paper.

Curtin, J. (1991), Women, Trade Unions and Equal Pay, Proceedings of Union/Tertiary Research Conference, 4: 154-172.

Dawson, J. (1992), Sex Equality and the Law of Employment, New Zealand Journal of Industrial Relations, 17(2): 149-160.

du Plessis Novitz, R. and Jaber, N. (1990), Pay Equity, the "Free" Market and State Intervention, New Zealand Journal of Industrial Relations , 15(3): 251-262.

Drago, R. (1989), The Extent of Wage Discrimination in Australia, Australian Bulletin of Labour, 15(4): 313-325.

Gregory, R.G., Anstie, R., Daly, A., and Ho, V. (1989), Women's Pay in Australia, Britain and the United States: the Role of Laws, Regulations and Human Capital, In R.T. Michael et al (eds), Pay Equity - Empirical Inquiries, Washington, National Academy Press.

Harbridge, R. (1993), The Employment Contracts Act: an Assessment of the Impact of the Legislation on Bargaining Arrangements, Paper to 7th AIRAANZ Conference, Auckland.

Hawke, A. (1992), How do Australian Part-time Workers Compare with their United States Counterparts?, Canberra, Australian National University Centre for Economic Policy Research, Discussion Paper 273.

Hill, L. (1992), Review of Out of the Chorus Line: the Progress of Women in New Zealand Unions, Women's Studies Association Newsletter, 13(2): 28-29.
Hyman, P. (1992), Pay Equity Developments in Five Countries - what can we learn from the different approaches?, Victoria Economic Commentaries, 9(2): 15-26.

New Zealand Federated Clerical, Administrative and Related Workers' Industrial Association of Workers (1986), Submissions to the Arbitration Court on Equal Pay and the Equal Pay Act 1972, in the case with Farmers Trading Company Limited and Others, Wellington.

Orr, E. (1986 a), The Arbitration Court's Role in Supervising the Equal Pay Act 1972, pape presented at Seminar on Equal Pay, Centre for Continuing Education, Victoria University of Wellington.

Orr, E. (1986 b), The Equal Pay Scene Revisited, unpublished paper.

Orr, E. (1988), Some Reflections and Proposals on Legislation to Promote Equal Pay for Work of Equal Value and Equal Opportunity, unpublished paper.

Osborne, R. (1976), Equal pay for equal work: a study of legislation in the United States, Canada, the United Kingdom and New Zealand, Doctor of Law Thesis, Cornell University.

Review Committee on Equal Pay (1979), Equal pay implementation in New Zealand Wellington, Report of a Committee appointed by the Minister of Labour.

Saar, P. (1992), Out of the Chorus Line - the Progress of Women in New Zealand Unions, Wellington, New Zealand Council of Trade Unions.

Sayers, J. (1991), Women, the Employment Contracts Act and Bargaining: a Discussion Paper, New Zealand Journal of Industrial Relations, 16(2): 159-166.

Tennet, E. (1986), Evidence in the case of New Zealand Federated Clerical, Administrative and Related Workers Industrial Association of Workers and Farmers Trading Company Limited and Others, Wellington.

Urban Research Associates, Hyman, P.J. and Clark, A. (1987), Equal Pay Study - Phase One Report, Wellington, Department of Labour. 